\title{
The Biological Chemistry of Gold
}

\section{ADVANCES IN UNDERSTANDING WITH MODERN TECHNIQUES}

\author{
P. J. Sadler \\ Chemistry Department, Birkbeck College, University of London
}

\begin{abstract}
Interest in the effects of gold compounds on biological systems ranges from their use for anti-inflammatory and anti-bacterial purposes to the study of the method of uptake of gold by micro-organisms. By the application of modern physical techniques new light is being shed on the mechanism of action of gold in these areas.
\end{abstract}

Although living things have a natural requirement for some metal ions, gold, as far as we know, is not one of them. We see from a glance at the d-block metals, Table $\mathrm{I}$, that none of the other members of the 3rd transition series are required, and that molybdenum stands alone in the 2nd series. The required ions activate particular biological pathways, for example cobalt for vitamin $\mathbf{B}_{12}$ (prevents pernicious anaemia), iron for haemoglobin (transportation of $\mathrm{O}_{2}$ ), zinc for carbonic arhydrase (catalyses $\mathrm{CO}_{2}$ hydration), copper for cytochrome oxidase (generates metabolic energy), and so on. We notice that copper, like gold, is in group IB and in some of its chemistry resembles gold. Why is gold not a natural requirement?

The low natural abundance and exceptional stability of metallic gold are probably both contributing factors, Living things have not developed a mechanism for converting metallic gold into a soluble form which can be utilised biochemically. However, a few plants, living in gold-rich soils, can accumulate gold $(1,2)$, perhaps helped by micro-organisms which can secrete amino acids for the purpose of dissolution (3). Concentrations of gold in plant ashes running from ten- to thirty-fold the normal concentrations are good indications of the sites of gold ores, although there are, of course, differences in gold accumulation between species; some types of grasses can accumulate as much as 100 grams of gold per ton.

The possibility arises of administering gold compounds to living things to produce a therapeutic effect-a thought that occurred to the Chinese in 2500 B.C.! Unlike them, we now have the tools for examining the action of gold in intimate detail, as will be appreciated from the illustration of Figure 1.

\section{Chemotherapy}

During those early times gold was regarded as a universal remedy which would favourably affect the course of all diseases. In the eighth century some alchemists attempted to prepare from metallic gold an elixir of life that would cure all diseases and confer eternal youth (4). In the thirteenth century gold, in the form of aurum potabile (gold dissolved in aqua regia and diluted with oil of rosemary or other essential oils) was recommended for the treatment of leprosy and many other diseases. Writing in about 1250, the famous encyclopaedist Bartholomaeus Anglicus extolled the virtues of gold for treating "cardiacal passion", "evils of the spleen and other evils", and even foreshadowed the use of gold for treating rheumatoid diseases: "gold comforteth

Table I

The d-Block Metals Essential for Living Things (bhown in red)

\begin{tabular}{lccccccccc}
\hline Sc & Ti & V & Cr? & Mn & Fe & Co & Ni & Cu & $\mathrm{Zn}$ \\
Y & Zr & Nb & Mo & Tc & Ru & Rh & Pd & Ag & Cd \\
La & Hf & Ta & W & Re & Os & Ir & Pt & $\mathrm{Au}$ & $\mathrm{Hg}$
\end{tabular}




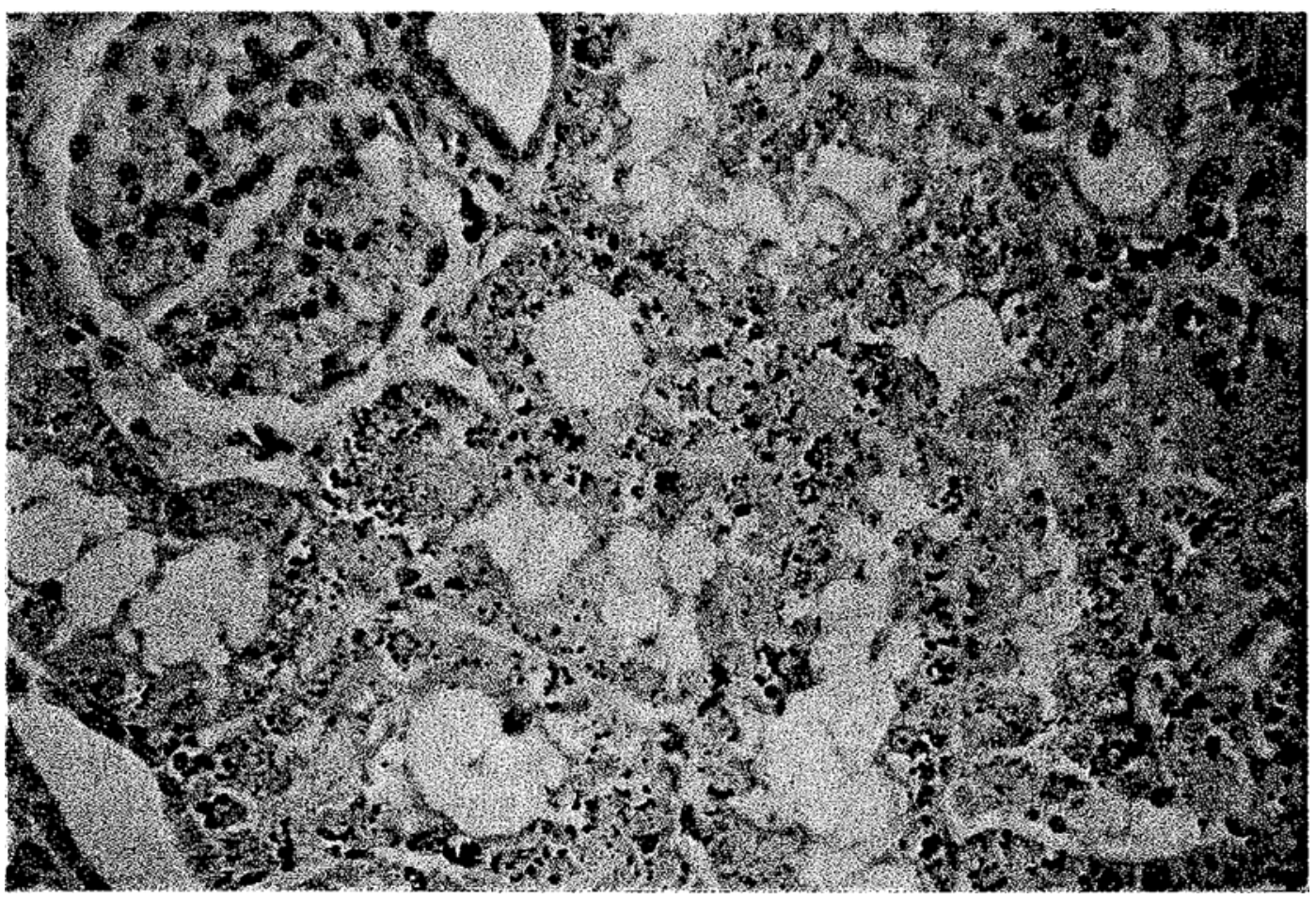

Fig. 1 By the use of a photochemical technique the target sites of the gold drng Myocrisin within the kidney of a rat are revealed. In this kidney section sites of gold deposition appear black, eell nuelei are stained red and the cell eytoplasm green. (B. Vernon-Roberts and J. I. Doré)

$\times \mathbf{3 5 0}$

lymmes ... it doth away with the sharpness of superfluities that growe in members and cleanseth them in that wise". As recently as the late eighteenth century gold was used for the treatment of nearly every illness, but with no biochemical basis for such treatment it is not surprising that confidence in its use was low.

It was Koch's discovery (5) in 1890 that $\mathrm{KAu}(\mathrm{CN})_{2}$ was lethal to the micro-organism responsible for tuberculosis (mycobacterium tuberculosis) in the test tube that paved the way for a sounder basis for gold therapy. This compound was administered to tuberculosis sufferers but, although there were favourable results, there were also serious toxic side-effects.

\section{Au(I)-thiols}

After intensive synthetic efforts in the 1920 s several Au(I)-thiols, AuSR, were prepared which were also stable in solution and biologically active,
Fig. 2 Graph showing the number of papers on gold treatment in tuhereulosis during the years 1925194. Of the first wave of publicationg hefore 1931 very few dealt primarily with toxic effeets (6)

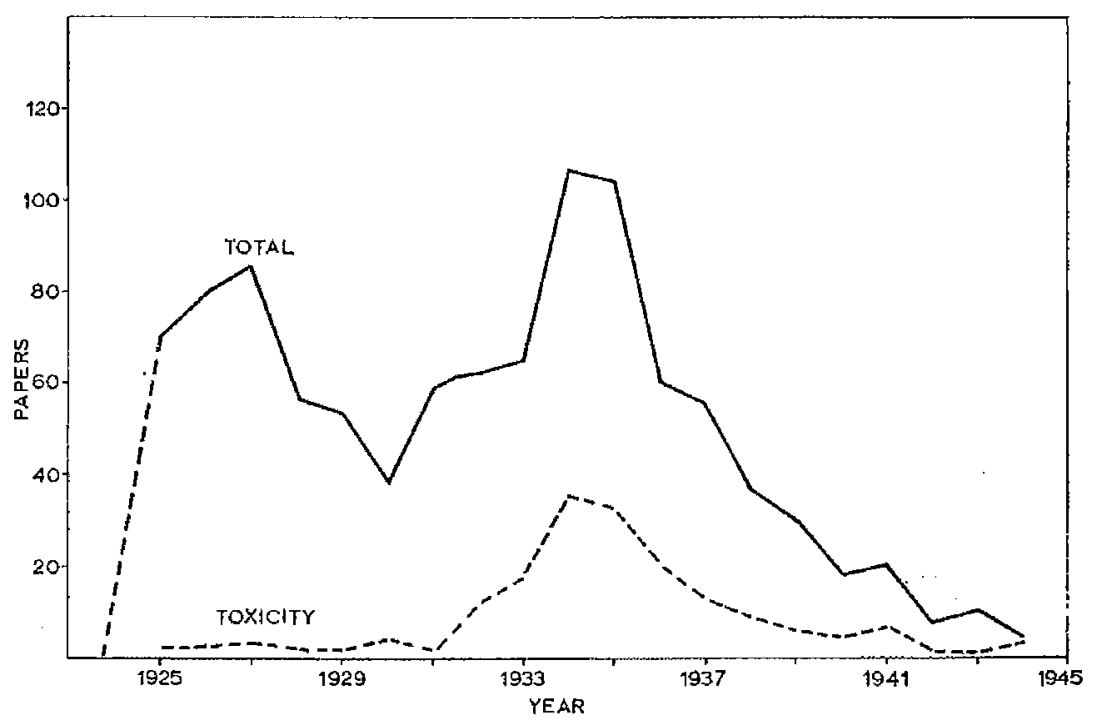


but much less toxic. Sodium aurothiosulphate (trade name "Sanocrysin"), sodium aurothiomalate ("Myocrisin"), sodium aurothiopropanol sulphonate ("Allochrysine") and aurothioglucose ("Solganal-BOleosum"), for example, all became popular. The period 1925 to 1935 , in which gold therapy in clinical tuberculosis flourished, has been termed the Gold Decade in tuberculosis treatment (6).

During this time Landé introduced these compounds for the treatment of rheumatoid arthritis (7), and it was quickly popularised by Forestier and others. Landé was impressed by the anti-bacterial effects, and assumed (mistakenly) that there was a relationship between arthritis and tuberculosis.

However, after 1935 there was a rapid rejection of gold drugs for tuberculosis treatment, without the immediate introduction of a substitute drug. We see from Figure 2 that interest waned in parallel with reports of toxic side-effects. Clearly laboratory groundwork on the curative effects was insecure and adequate critical clinical trials were lacking (6).

Disodium aurothiomalate and aurothioglucose, Table II, remain in clinical use today for the treatment of rheumatoid arthritis. Controlled trials by the Empire Rheumatism Council in 1960 (8) have confirmed the beneficial effect of gold drugs, and according to recent medical opinion (9) they are as effective as any other available drug for the difficult cases and are among the few that can alter the course of the disease, Although some patients can safely remain on gold therapy for many years, about 35 per cent do suffer some toxic side-reactions.
The search for less toxic gold drugs has recently lead to animal trials of $\mathrm{Au}(\mathrm{I})$-phosphines.

\section{Au(1)-phosphines}

Gold-phosphine complexes of the type $R_{3} P$ AuX ( $\mathrm{X}=$ halide, $\mathrm{R}=$ alkyl) have been known since about 1870 and are readily prepared from $A u($ III) and two equivalents of phosphine. They possess remarkable stability and can usually be distilled without decomposition at low pressures. However, it is only recently that they have been tested for anti-inflammatory activity. Workers at Smith, Kline and French Laboratories in Philadelphia not only find that they are effective against polyarthritis in experimental animals, but also that they can be administered orally $(10,11,12)$, whereas aurothiomalate is effective only when given intramuscularly. Moreover harmful retention of gold by the kidney is very much reduced. Table III lists some active $\mathrm{Au}(\mathrm{I})$-phosphine drugs and also some inactive ones. They have recently prepared and tested a wide variety of these derivatives.

The best therapeutic response is accompanied by the highest serum gold level, and the extent of absorption is dependent on the nature of the phosphine. The ethyl phosphine derivatives appear to be the most active.

\section{Gold Drugs in Solution}

Unlike many organic drugs the active form of a metallodrug in vivo may not be that indicated by the molecular formula. For example, the new antitumour drug cis-Pt $\left(\mathrm{NH}_{3}\right)_{2} \mathrm{Cl}_{2}$ is thought to hydrolyse

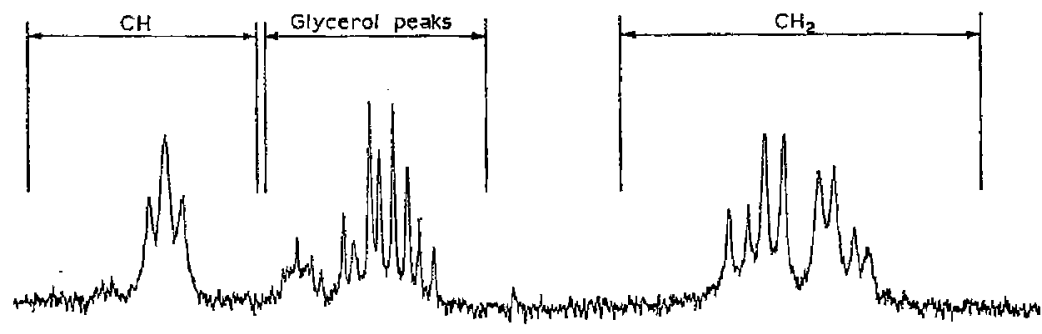

Fig. 3 III NMR speetra of auriothiomalate $(\mathbf{0 . 3} \mathrm{M})$. Commercially available samples contain about 0.3 moles of glycerol per auro. thiomalate (the areas under the peaks are proportional to amounts present). Dramatic changes in the $\mathrm{CH}$ and $\mathrm{CH}_{2}$ peaks of anrothiomalate occur on adding $\mathrm{NaCl}(1 \mathrm{M})$. This change is not secn with thiomalate itself, and is due to association of aurothiomalate molecules

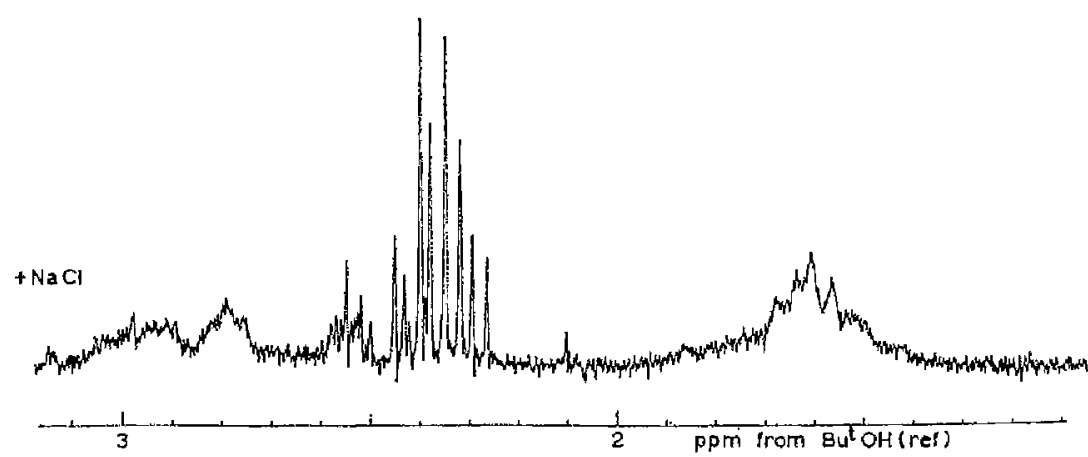


Table li

Anti-inflammatory Gold Drugs in Clinical Use

Molccular Formula<smiles>CCCSC(CC(=O)O)C(=O)O[Na]</smiles><smiles>CCCCCCCCO</smiles>

Chemical Name

disodium aurothiomalate

aurothioglucose
Trade Name

Myocrisin
Solganal-BOleosum upon entering cells to give the reactive species cis- $\mathrm{Pt}\left(\mathrm{NH}_{3}\right)_{2}\left(\mathrm{H}_{2} \mathrm{O}\right) \mathrm{Cl}^{+}$, and the diaquo form. It has recently been pointed out (13) that aurothiomalate will have at least 2-coordinate $\mathrm{Au}(\mathrm{I})$ in solution. Ultracentrifuge and other measurements have demon- strated (14) the ease of polymerisation of this drug in solution and that the process is dependent on the other ions in solution and can occur in blood serum. The changes in the ${ }^{1} \mathrm{H}$ nuclear magnetic resonance spectrum of aurothiomalate on addition of salt,

Table III

Potential Au(I)-Phosphine Anti-inflammatory Gold Drugs in Clinical Use

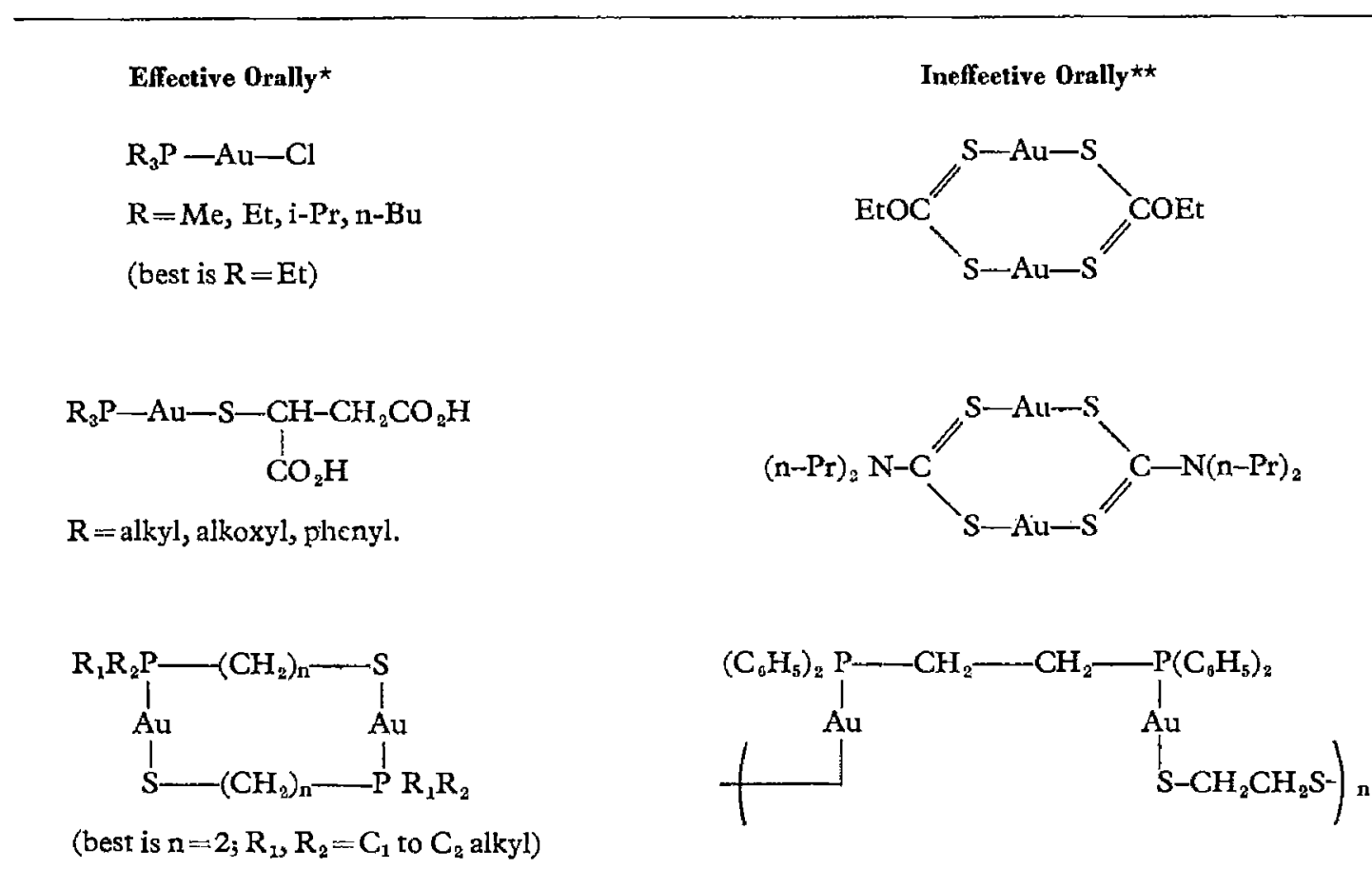

¿Effective against hindleg inflammation produced by a bacterium injected into the hindpaw of a ra $\star \star$ Probably due to lack of absorption into bloodstream 


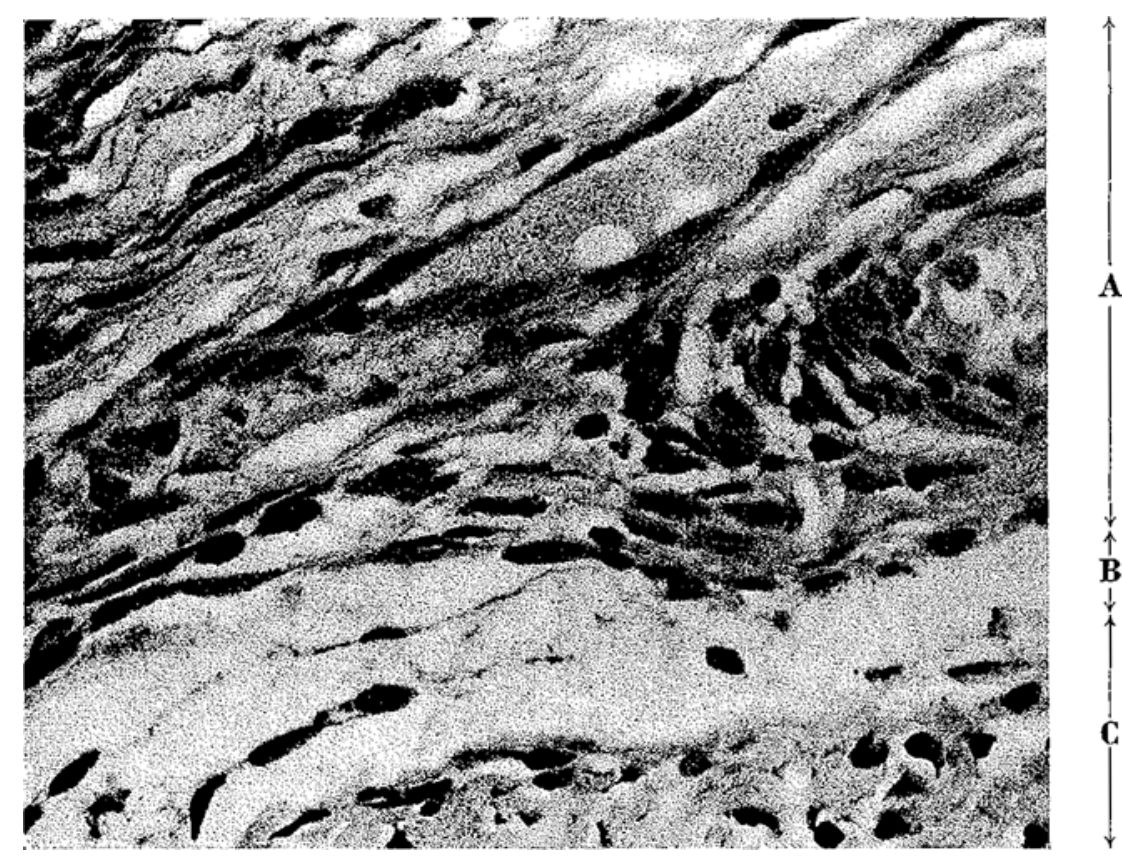

Iig. 4 Section of human synovium from a patient with rhcumatoid arthritis currently receiving aurothiomalate. The greatly inflamed subintina (area $\mathbf{A}$ ) contains many cells laden with gold grains (black deposits), separated from the deeper joint tissue (area C) by a layer of fatty tissue (area B). (B. Vernon-Roberts and J. L. Doré)

Table IV

Gold Derivatives of Crystalline Proteins and Enzymes

\begin{tabular}{|c|c|c|c|c|}
\hline $\begin{array}{l}\text { Gold Labelling } \\
\text { Agent }\end{array}$ & $\begin{array}{l}\text { Protein or } \\
\text { Enzyme }\end{array}$ & $\begin{array}{l}\text { Molecular } \\
\text { Weight }\end{array}$ & $\begin{array}{l}\text { Gold Binding } \\
\text { Sites* }\end{array}$ & Reference \\
\hline \multirow[t]{3}{*}{$\mathrm{Au}^{\mathrm{I}}(\mathrm{CN})_{2}^{-}$} & flavodoxin & 15,000 & $\begin{array}{l}\text { Cys 128 } \\
\text { (Cys 53) }\end{array}$ & 16 \\
\hline & $\begin{array}{l}\text { carbonic } \\
\text { anhydrase }\end{array}$ & 30,000 & $\begin{array}{l}\mathrm{His} 128 / \mathrm{H}_{2} \mathrm{O} \\
\text { (see Figure } 5^{\star \star} \text { ) }\end{array}$ & 17 \\
\hline & $\begin{array}{l}\text { liver alcohol } \\
\text { dehydrogenase }\end{array}$ & 80,000 & $\begin{array}{l}\text { Cys } 240 \text { (adenine } \\
\text { hydrophobic pocket) }\end{array}$ & 18 \\
\hline \multirow[t]{7}{*}{$\mathrm{Aul}^{\mathrm{III}} \mathrm{Cl}_{4}^{-}$} & cytochrome $\mathrm{C}_{2}$ & 12,000 & His 42 (Asp 3) & 19 \\
\hline & lysozyme & 14,600 & Arg 14 & 20 \\
\hline & myoglobin & 17,800 & His B5/His GH1 & 21 \\
\hline & adenylate kinase & 22,000 & Cys? & 22 \\
\hline & $\begin{array}{l}\text { yeast phosphoglycerate } \\
\text { kinase }\end{array}$ & 45,000 & Cys ? & 23 \\
\hline & haemoglobin (bloodworm) & 68,000 & Cys 30 (His 72) & 24 \\
\hline & lactate dehydrogenase & 140,000 & Cys & 25 \\
\hline \multirow[t]{3}{*}{$\mathrm{AuI}_{4}^{-}$} & $\begin{array}{l}\text { Bence-Jones protein } \\
\text { (part of an immuno- } \\
\text { globulin) }\end{array}$ & 12,500 & $?$ & 26 \\
\hline & myoglobin & 17,000 & close to the haem group & 21 \\
\hline & chymotrypsin & 25,300 & $?$ & 27 \\
\hline
\end{tabular}

*In some cases the exact nature of the binding groups for gold is uncertain, and the resolution of the X-ray structure determination is often insufficient to define completely the gold coordination sphere. The numbers refer to the position of the amino acid in the protein; for further details see references.

** Dr. S. Lindslog has informed me that the residue labelled HIS 128 in Figure 5 is now thought to be a phenylalanine residue, Phe 129, which cannot H-bond with (AuCN) $_{2}^{-}$. Further investigations are in progress to determine the interactions which hold the gold ion in this position. 

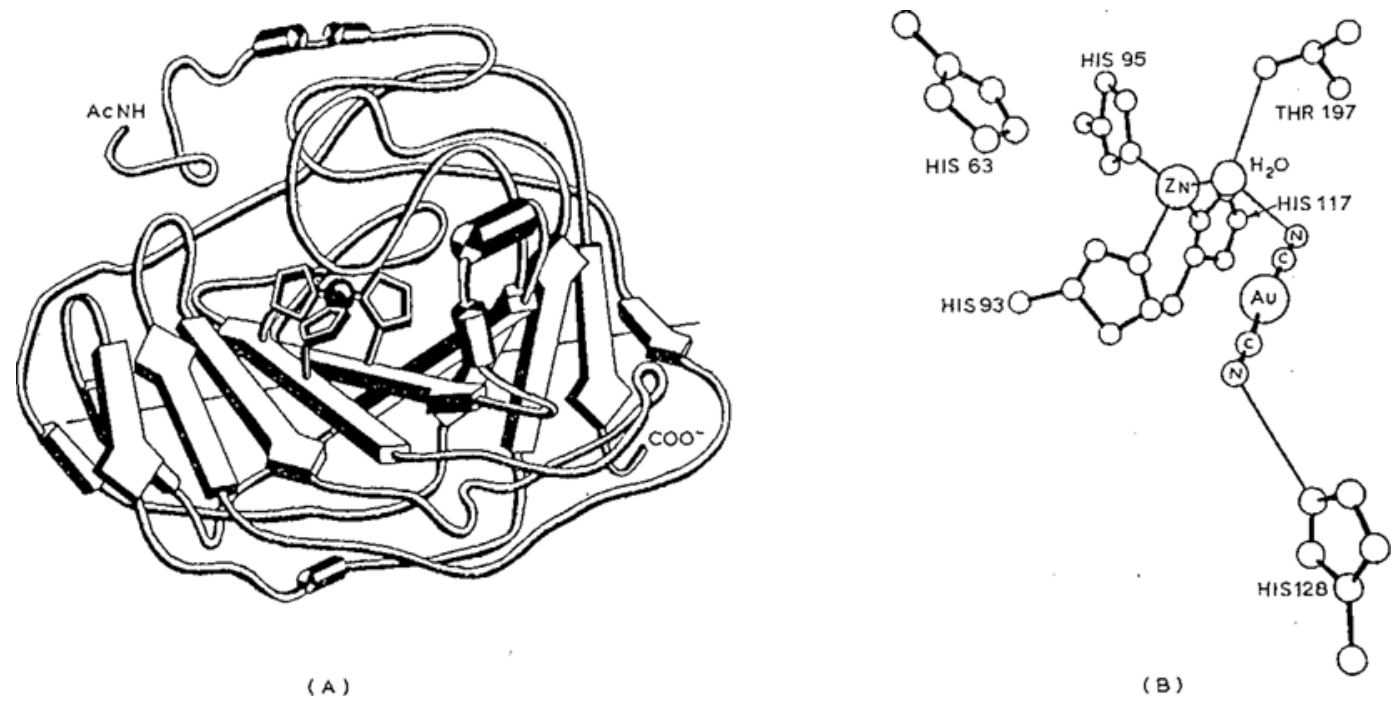

Fig. 5 The binding site for linear $\mathrm{Au}(\mathrm{CN})_{2}^{-}$ion on the enzyme carbonic anhydrase, as seen by $\mathrm{X}$-ray crystallography. On the left in (A) is shown schematically the outline of the polypeptide backhone of the enzyme. The black sphere is $\mathrm{Zn}^{2+}$ bonded to 3 histidine side ehains. $\mathrm{Au}(\mathrm{CN})_{2}^{-}$binds in the vieinity of $\mathrm{Zn}^{2+}$ as shown in the elose-up in (B) (from 17)

shown in Figure 3, clearly indicate a structural change, and the behaviour of the thiomalate ligand can also be observed by ${ }^{13} \mathrm{C}$ NMR spectroscopy.

Once aurothiomalate enters the serum it is largely taken up by a protein called albumin, and details of its ultimate target sites are beginning to emerge.

\section{Site of Action}

After injection aurothiomalate seems to enter many cells in the body, but a closer examination shows that much gold occurs in localised deposits. Figure 4 shows a section of human synovium from a patient on gold therapy. The gold is found in localised deposits within cells, called macrophages, which are usually responsible for the removal of "foreign bodies". These cells may contain enzymes responsible for rheumatoid inflammation, and gold may be inhibiting their action.

The sites of gold deposition in tissues is elegantly demonstrated by the use of photochemical techniques (15). After staining the tissue section with silver ions, exposure to light followed by a developing procedure leaves deposits of metallic silver at gold sites and these are readily seen in the electron microscope. Sensitisation of silver halide emulsions by gold salts is well-known and this procedure, as well as further stains for other parts of the cell, was used to obtain Figure 1, on page 111 , which shows a kidney section. Hold-up of gold here can cause toxicity problems.
A full understanding of the action of gold drugs requires a knowledge of gold binding at the molecular level. For example, how gold ions interact with enzymes and proteins.

\section{Enzymes and Proteins}

For several years crystallographers have been labelling crystalline enzymes and proteins with gold as an essential step for solving a phasing problem when determining three-dimensional structures by $\mathrm{X}$-ray methods. Gold has a high X-ray scattering power, and can readily be located in the electron density map. In Table IV some examples are listed, while Figure 5 shows that the gold-binding site on a biological macromolecule can be pin-pointed. Either the gold labelling-agent is co-crystallised with the enzyme or-more usually-diffused into enzyme crystals. Although in some cases the exact details of the gold coordination sphere are unclear in the final three-dimensional structure, we shall see further refinements here. It is clear that the species used for labelling is not necessarily that which binds. For example, although $\mathrm{KAuI}_{4}$ may be used, decomposition in solution is well-known:

$$
\mathrm{Aur}_{4}^{-} \rightleftharpoons \mathrm{AuI}_{2}^{-}+\mathrm{I}_{2}
$$

and the enzyme may therefore become labelled with $\mathrm{Au}(\mathrm{I})$.

From Table IV it can be seen that gold often binds to sulphydryl groups in proteins. These are provided 


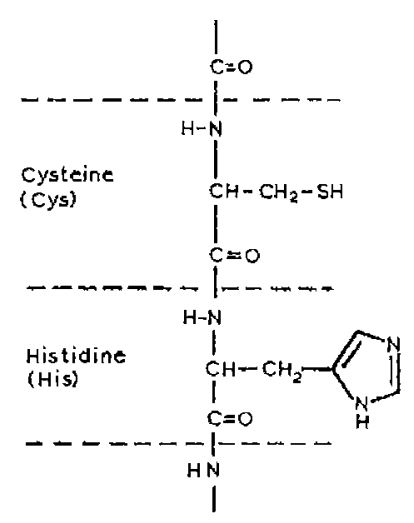

Fig. $6 \mathrm{~A}$ protein is a polymer of amino acids. Part of a protein containing the amino acids histidine and cygtcine is shown. These are targets for $\mathrm{Au}$ (III) and $\mathrm{Au}(\mathrm{I})$ binding as shown in Table IV

by the amino acid cysteine, shown in Figure 6 , and there are many important enzymes now known to require a free Cys $\mathrm{SH}$ group for activity. If this is blocked with gold the enzyme cannot function. The next step is to crystallise enzymes in the presence of gold thiol and phosphine anti-inflammatory drugs.

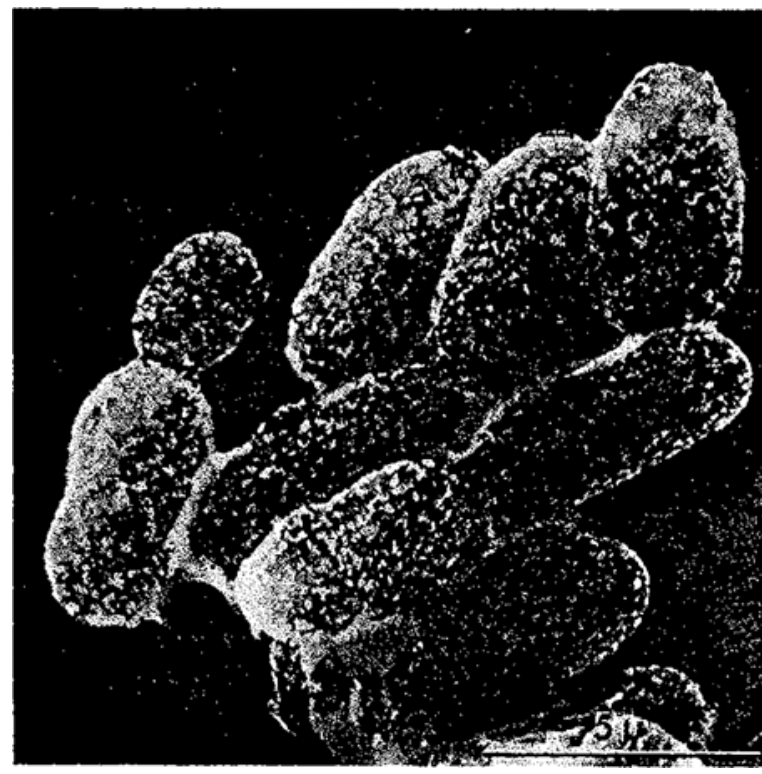

Fig. 7 Colloidal gold markers on the surface of Candida utilis (fungus) cells. When these cells are introduced into the bloodstream of an animal, antibodies (large proteins) are produced which bind to the surface of these foreign cells to bring about their destruction. By adsorbing the antillodies on to $60 \mathrm{~nm}$ colloidal gold particles, and then allowing them to bind to the cells, the distribution of antibody sites on the cell surface is readily revealcd in the scanning electron microscope, as shown (28)
Labelling biological material for viewing by electron microscopy can also be very fruitful. The most popular label is colloidal gold.

\section{Colloidal Gold}

The reduction of $\mathrm{Au}(\mathrm{III})$ compounds in aqueous solution frequently leads to gold particles dispersed in a homogeneous medium, i.e., a colloidal solution. These are usually attractively coloured, ranging from red (small particles), violet, to blue (large particles), and are very stable. The Royal Institution in London, for example, still has three blue/ruby-coloured colloidal gold solutions prepared by Faraday in 1856 . Flocculation occurs easily in the presence of salts, and to maintain a colloid with small particle size a protein, such as albumin, can be added. This interaction between colloidal gold and the protein can be used to advantage.

For example, if an antibody binds to the surface of the cell it cannot be seen under the electron microscope, since the electron scattering power of all

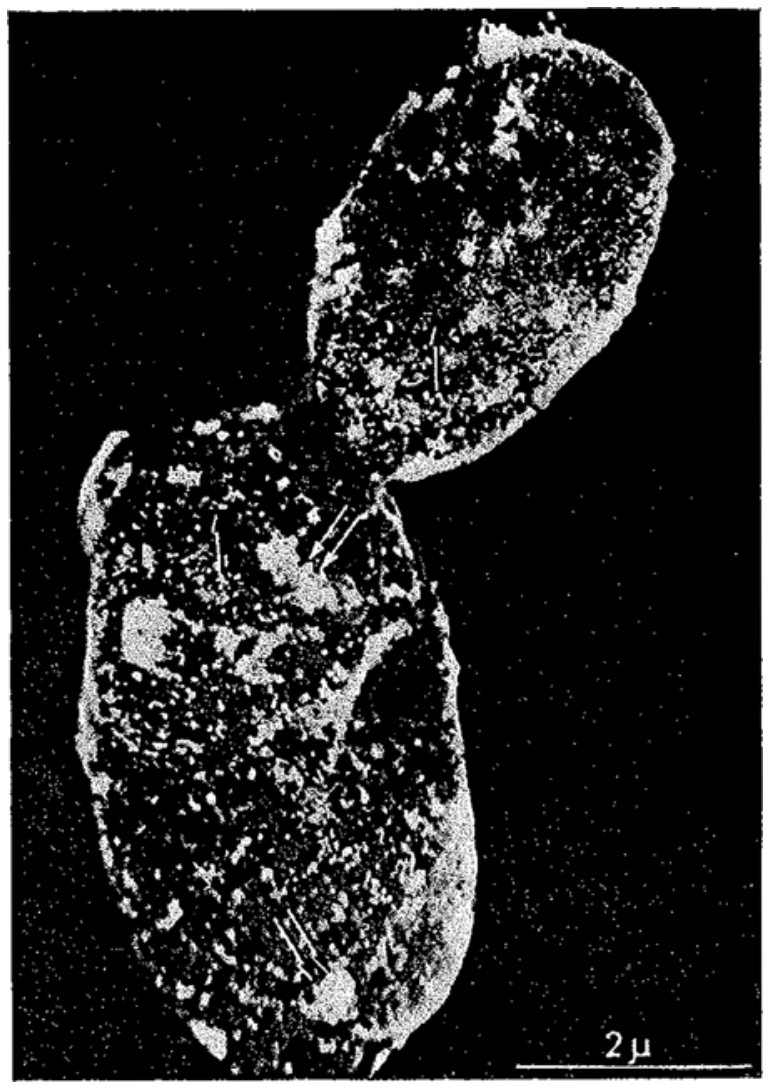

Fig. 8 A double labelling experiment with colloidal gold on Candida utilis cells. The first marker is Concanavalin A (a protein which hinds specifically to the carbohydrate mannan) adsorbed on to $40 \mathrm{~nm}$ colloidal gold particlcs. This idcutifies the manuan sites on the surface $(\uparrow)$. The sccond markers are antibodies adsorbel on to $\mathbf{8 0} \mathrm{nm}$ colloilal gold particles which locate non "mannan sites $(\uparrow \uparrow\rangle$. The first marker is distributed homogeneously, hut the sccond occurs only in patches (28) 


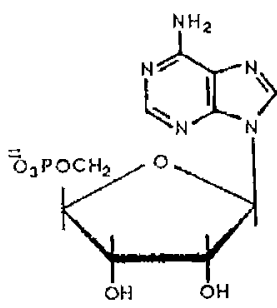

(A)

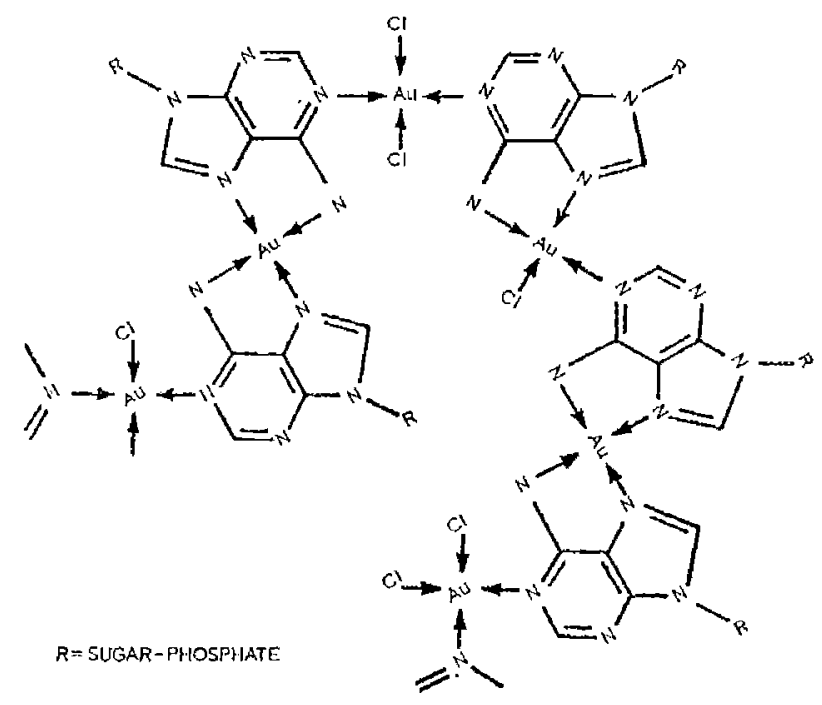

(B)

Fig. 9 (A) The nucleotide adenosine monophosphate, a constituent of RNA.

(B) Possible structure of an Au(III)-adenosine aidluct (32)

the atoms, mainly $\mathrm{C}, \mathrm{H}, \mathrm{O}, \mathrm{N}$, is very low. However, an antibody labelled with colloidal gold can often retain its ability to bind to a cell surface, and the dense region of gold, with its high electron scattering power, is now a well-contrasted marker. Figures 7 and 8 illustrate how mannan receptors at the surface of the fungus cells candida utilis can be localised by stabilised colloidal gold granules coated with either anti-mannan antibodies or the mannan-binding protein concanavalin A (28).

The double labelling technique is possible because the particles can be prepared with defined sizes. The method of Frens (29) involves reduction of $\mathrm{HAuCl}_{4}$ with sodium citrate and gives monodisperse solutions with particles of average diameter $160 \mathrm{up}$ to $1470 \AA$. Flocculation of protein-coated granules in the presence of excess protein can be prevented by addition of polyethylene glycol (28).

The uptake of radioactive colloidal gold has been recommended (30) as a convenient assay for cellular hypersensitivity, since there is an enhanced uptake of colloidal gold by macrophages isolated from guinea pigs sensitised by tuberculin. A specific chemical substance appears to be released by lymphocytes (cells which produce antibodies) to stimulate the uptake of colloidal gold by macrophages. To label the genetic material of cells, rather than proteins, $\mathrm{Au}(\mathrm{III})$ has been advocated.

\section{Au(III)-Nucleic Acids}

The storage and transmission of genetic information in cells is provided by the macromolecular nucleic acids deoxyribonucleic acid (DNA) and ribonucleic acid (RNA). The individual nucleotide units are joined by phosphate-ester linkages. A brown gold DNA adduct can be isolated from chloroaurate-DNA mixtures (31). $\mathrm{Au}(\mathrm{III})$ has a high affinity for $\mathrm{N}$ ligands and, in particular, for $\mathrm{NH}_{2}$ groups. Strong complexes are formed with adenine nucleotides, for example, as shown in Figure 9 (32). The goldadenine nucleotide adducts have potential applications in cytochemistry to identify intracellular enzyme sites. The enzyme acid phosphatase cleaves the phosphate group and an electron dense product is deposited at the enzyme site and is seen in the electron micrograph (33).

Polyadenylic acid can be stained with $\mathrm{HAuCl}_{4}$ to produce a three-fold enhancement in contrast when viewed by electron microscopy. The staining can be selective for nucleotides. Polyuridylic acid (no $\mathrm{NH}_{2}$ groups) is not stained.

Binding of $\mathrm{Au}$ (III) to DNA could interfere with cell division process, but this is just what might be required of a potential $\mathrm{Au}$ (III) anti-tumour agent. Ir is with great interest that we await further news of the compound $\left[\mathrm{Au}(5-\mathrm{du})_{2} \mathrm{Cl}_{2}\right] \mathrm{Cl} . \mathrm{HCl}$ which has recently been reported to show anti-tumour activity in mice (34). 5-du is 5-diazouracil.

\section{Gold and Obesity}

It is now well-established $(35,36)$ that injection of aurothioglucose into mice results in obesity. Increases in body-weight by up to one-third have been observed, and the effect is specific for aurothio- 
glucose; the thiomalate, thiocaproic acid, thioglycerol, thioglycoanilide and thiosulphate derivatives of $\mathrm{Au}(\mathrm{I})$ are inactive. Evidently a specific in vivo glucose receptor is destroyed by the presence of gold. Such studies may improve our understanding of the nature of obesity.

\section{Conclusion}

There is widespread interest in the effect of gold compounds on biological systems, especially since, with the aid of modern physical techniques, we can begin to map out the activity of gold in molecular terms. We can often locate gold inside cells and in some cases pin-point its binding sites on macromolecules such as enzymes. As this knowledge increases, so the design of new gold compounds, either as metallodrugs or as heavy-atom labels, will undoubtedly improve.

\section{Acknowledgements}

I am very grateful to Dr B. Vernon-Roberts and $\mathrm{Mr} \mathrm{J}$. L. Doré of the London Hospital Medical College, Dr C. Danpure of the Clinical Research Centre, Northwick Park, Dr P. D'Arcy Hart of the National Institute for Medical Research and Dr L. B. Hunt of Johnson Matthey \& Co Ltd for discussion and for supplying material as indicated in the text.

\section{References}

1 R. M. Talipov and Sh. Khatamov, Uzb. Geol.Zh., 1974, 18, 23-7

2 R. M. Talipov and Sh. Khatamov, Uzb. Geol. Zh., 1973, 17, 26-31

3 E. D. Korobushkina, A. S. Chernyak and G. G. Mineer, Mikrobiologiya, 1974, 43, 49-54

4 Metabolism, Pharmacology and Therapeutic Uses of Gold Compounds by W. D. Block and K. Van Goor, Am. Lect. Series 282 , published by C. C. Thomas, Springfield, Illinois, U.S.A., 1954

5 R. Koch, Deutsche Med. Wchnschr., 1890, 16, 756

6 P. D'Arcy Hart, Brit. Med. J., 1946, 2, 805 and 809

7 K. Landé, Muknch. Med. Wchschr., 1927, 74, 1132

8 ERC Trial, Ann. Rheum. Dis., 1961, 20, 315

9 T. J. Constable, A. P. Crockson, R. A. Crockson and B. McConkey, The Lancet, 1975, May 24, 1176-79

10 B. M. Sutton, E. McGusty, D. T. Walz and M. J. Di Martino, F. Med. Chem., 1972, 15, 1095-98

11 D. T. Walz, M. J. Di Martino, B. Sutton and A. Misher, F. Pharm. Exp. Ther., 1972, 181, 292-297
12 J. Weinstock, B. M. Sutton, G. Y. Kuo, D. T. Walz and M. J. Dí Martino, f. Med. Chem., 1974, 17, 139-140

13 P. J. Sadler, Structure and Bonding, in the press

14 A. A. Isab, P. J. Sadler, C. J. Danpure, D. A. Fyfe and P. A. Charlwood, manuscript in preparation.

$15 \mathrm{~J}$. L. Doré, Thesis for Diplomate Fellowship to the Institute of Medical Laboratory Sciences, London, 1974

16 R. M. Burnett, G. D. Darling, D. S. Kendall, M. E. LcQuesne, S. G. Mayhew, W. W. Smith and M. L. Ludwig, f. Biol. Chem., 1974, 249, 4383-92

17 S. Lindskog, L. E. Henderson, K, K. Kannan, A. Liljas, P. O. Nyman and B. Strandberg, The Enzymes, Ed. by P. D. Boyer, Vol. V, 587-665, published by Academic Press, London, 1971

18 H. Eklund, B. Nordström, E. Zeppezauer, G. Söderlund, I. Ohlsson, T. Boieve, B-O. Söderberg, O. Tapia, C-I. Bränden and A. Akeson, F. Mol. Biol., 1976, 102, 25-59

19 F. R. Salemme, S. T. Freer, N. H. Xuong, R. A. Alden and J. Kraut, F. Biol. Chem., 1973, 248, 3910-21

20 C. C. F. Blake, Adv. Prot. Chem., 1968, 28, 39

21 H. Scouloudi, Proc. Roy. Soc. Lond., 1960, A258, 181; M. M. Bluhm, G. Bodo, H. M. Dintzis and J. C. Kendrew, Proc. Roy. Soc. Lond., 1958, A246, 369

22 G. E. Schulz, K. Bjedermann, W. Kabsch and R. H. Schirmer, F. Mol. Biol., 1973, 80, 857-64

23 P. L. Wendell, T. N. Bryant and H. C. Watson, Nature New Biol., 1972, 240, 134-136

24 E. A. Padlan and W. E. Love, 7 , Biol. Chem., 1974, 249, 4067-78

25 M. J. Adams, D. J. Haas, B. A. Jeffery, A. McPherson, H. L. Mermall, M. G. Rossmann, R. W. Schevitz and A. J. Wonacott, F. Mol. Biol., 1969, 41, 159

26 B. C. Wang, C. S. Yoo and M. Sax, F. Mol. Biol., 1974, $87,505-508$

27 A. Tulinsky, N. V. Mani, C. N. Morimoto and R. L. Vandlen, Acta Cryst., 1973, A29, 1309-22

$28 \mathrm{M}$. Horisberger, J. Rosset and $\mathrm{H}$. Bauer, Experientia, $1975,31,1147$

29 G. Frens, Nature Phys. Sci., 1973, 241, 20-22

30 C. J. Meade, P. J. Lachman and S. Bremner, $\mathcal{F}_{\text {. Immunol., }}$ $1974,27,227$

31 C. K. S. Pillai and U. S. Nandi, Biopolymers., 1973, 11, 1431

32 D. W. Gibson, M. Beer and R. J. Barrnett, Biochemistry, $1971,10,3669-3679$

33 J. T. R. Fitzsimons, D. W. Gibson and R. J. Barrnett, 7. Histochem. Cytochem., 1970, 18, 673-4

34 C. Dragulescu, J. Heller, A. Maurer, S. Policec, V. Topeui, M. Csalci, S, Kirschner, S. Kravitz and R. Moraski, Inst. Coord. Chem. Conference, 1974, XVI, 1.9

35 J. Mayer and N. B. Marshall, Nature, 1956, 178, 1399-40 36 R.J. Martin and P. Lamprey, Liffe Sci., 1974, 14, 1121-31

\section{Gold Coated Glass for Solar Insulation}

Several methods of reducing the effects of solar radiation in buildings are now avaitable, including the use of a gold film applied to the inner surface of the outside panes of windows. This gold coating allows part of the visible radiation to pass through while reflecting much of the infra-red. In a paper by Werner Klein of the Jenaer Glaswerk Schott und Genossen in Mainz, West Germany (Glass, 1976, $53,(3), 91-94)$, the special property of gold that makes it suitable for this purpose is described-its low emission coefficient for long-wave radiation. Thus gold coating emits less long-wave radiation to the inside of a room than the outside pane emits to the atmosphere. In addition, this property of gold results in a considerable improvement in thermal insulation in winter by a marked improvement in the coefficient of heat transfer.

The intensive reflection colour from gold-coated glass does, however, pose one problem to the architect. This has been largely overcome by the introduction of reflection-reducing interference layers to give blue-toviolet reflection colours that are architecturally attractive, while they increase substantially the amount of light transmitted in the yellow-to-green region. 